African Crop Science Journal by African Crop Science Society is licensed under a Creative Commons Attribution 3.0 Uganda License. Based on a work at www.ajol.info/ and www.bioline.org.br/cs DOI: http://dx.doi.org/10.4314/acsj.v25i3.8

\title{
SORGHUM HEAD BUG INFESTATION AND MOULD INFECTION ON THE GRAIN QUALITY OF SORGHUM IN NORTHERN GHANA
}

\author{
J.H. AHETO, V.Y. EZIAH ${ }^{1}$, I.D.K. ATOKPLE ${ }^{2}$ and K. OPARE-OBUOBI ${ }^{3}$ \\ P. O. Box TT 38, Tema, Ghana \\ ${ }^{1}$ Department of Crop Science, P. O. Box LG44, Legon, Ghana \\ ${ }^{2}$ CSIR- Savanna Agricultural Research Institute, P. O. Box 52, Tamale, Ghana \\ ${ }^{3}$ CSIR- Savanna Agricultural Research Institute, Sorghum Improvement Section, P. O. Box TL 52, \\ Tamale, Ghana \\ Corresponding author: eziahvin@yahoo.com
}

(Received 14 December, 2015; accepted 1 August, 2017)

\begin{abstract}
Sorghum (Sorghum bicolor) panicle is reported to be attacked by a myriad of insect pest species, whose infestation predisposes the grains to fungal infection, thereby compromising their quality. A complex of bugs has been reported to infest sorghum, thereby affecting quality of grains in West Africa. The objective of this study was to investigate the effect of head bug (Eurystylus oldi (POPPIUS) infestation and mould infection on sorghum grain quality. An experiment consisting of eight sorghum breeding lines (two parental checks and six $\mathrm{F}_{8}$ derivatives), was carried out in fields at three Agro-ecological Zones (Nyankpala, Damongo and Manga) in Northern Ghana. Results showed that damage caused by head bug populations per panicle were not significant $(\mathrm{P}>0.05)$. Head bug damage was, however, found to be highly correlated with panicle grain mould ratings (PGMR) at all three locations. This points to the significant roles head bug damage plays in fungal infection of sorghum grains. The derivatives, on the other hand, suffered less PGMR than the compact headed Kapaala, across the three locations. The three dominant fungi isolated at Manga and Nyankpala included those of the genera Curvularia sp. (31.6 and $31.4 \%$, respectively), Fusarium sp. (22.3 and 27.6\%, respectively) and Thielaviopsis sp. (20.3 and 20.9\%, respectively). At Damongo, Fusarium sp. (29.6\%), Curvularia sp. (23.6\%) and Mucor sp. (17.2\%) were dominant. Grain quality, in terms of head bug and mould damage ratings, showed the following lines emerging superior at Manga (SARSORG-MRG-2011-3, SARSORG-SBG-2011-5 and SARSORG-SRG-2011-6), at Damongo (SARSORG-TRG-2011-1, SARSORG-SBG-2011-5 and SARSORG-MBG-2011-4) and at Nyankpala (SARSORG-MBG-2011-4, SARSORG-MRG-2011-3 and SARSORG-TRG-2011-1) and; thus suggest they may possess some desirable traits for which they could be selected for further improvement.
\end{abstract}

Key Words: Curvularia, Eurystylus oldi, Sorghum bicolor

\section{RÉSUMÉ}

La panicule du sorgho (Sorghum bicolor) a été rapportée d'être attaquée par une multitude d'espèces d'insectes pestes, dont l'infestation prédispose les grains à l'infection des champignons, par conséquent compromet leur qualité. Un complexe de punaises a été rapporté d'infester le sorgho, donc affecte la qualité des grains en Afrique de l'Ouest. L'objectif de cette étude était d'investiguer l'effet de l'infestation des punaises de tête (Eurystylus oldi, POPPIUS) et des moisissures sur la qualité des grains du sorgho. Une expérimentation comportant huit lignées améliorées du sorgho (deux contrôles parentaux et six $\mathrm{F}_{8}$ dérivées), était conduite au champ en trois zones agro-écologiques (Nyankpala, Damongo et Manga) au Nord du Ghana. Les résultats ont montré que les dommages 
causés par les populations de punaises de tête sur la panicule n'étaient pas significatifs $(\mathrm{P}>0,05)$. Le dommage de la punaise de tête était, toutefois, retrouvé hautement corrélé avec les scores de panicule de grains moisies (PGMR) à toutes les trois locations. Ceci montre le rôle significatif que joue la punaise de tête dans l'infection fongique des grains du sorgho. Les dérivées, d'autre part, ont souffert moins de PGMR que le Kapaala à tête compacte, à travers les trois locations. Les trois champignons dominants isolés à Manga et Nyankpala comprennent ceux du genre Curvularia sp. (31,6 et 31,4\%, respectivement), Fusarium sp. (22,3 et 27,6\%, respectivement) et Thielaviopsis sp. (20,3 et 20,9\%, respectivement). A Damongo, Fusarium sp. (29,6\%), Curvularia sp. (23,6\%) et Mucor sp. (17,2\%) étaient dominants. La qualité du grain, en termes des scores du dommage de punaise de tête et des moisissures, a montré que les lignées suivantes étaient supérieures à Manga (SARSORG-MRG-2011-3, SARSORG-SBG-2011-5 et SARSORG-SRG-2011-6), à Damongo (SARSORG-TRG-2011-1, SARSORG-SBG2011-5 et SARSORG-MBG-2011-4) et à Nyankpala (SARSORG-MBG-2011-4, SARSORG-MRG-2011-3 et SARSORG-TRG-2011-1) et ; donc suggère qu' ils pourraient posséder quelques traits désirables pour lesquels ils pourraient être sélectionnés pour une meilleure amélioration.

Mots Clés: Curvularia, Eurystylus oldi, Sorghum bicolor

\section{INTRODUCTION}

Sorghum (Sorghum bicolor Moench) is Africa's second most important cereal crop after maize (Zea mays L.), but the most important cereal in the Guinea and Sudan savannah regions of West Africa (Mishra et al., 2008). In Ghana, sorghum is mainly grown in the semi-arid zones, comprising of the three Northern regions usually characterised by erratic and low rainfall.

Despite the important role that the crop plays in the livelihood of populations in the country (Kudadjie et al., 2004), production is constrained by a myriad of biotic and abiotic factors, including insect pests, of which head bugs (Eurystylus oldi) constitute a major entity (Atokple, 1993; Gerda and Christopher, 2007; Ochieng et al., 2011).

The sorghum head bug (Eurystylus oldi POPPIUS) belongs to the family Miridae. It is one of the most renowned panicle feeding insect pests that feeds on sorghum grains in West and Central Africa. Female adults deposit eggs on the panicles, soon after booting, and both adults and nymphs suck sap from the developing grain, causing it to shrink, thus reducing yield (Sharma, 1985; Rana and Singh, 1995; Kudadjie-Freeman et al., 2008). Little information is available on head bugs and their activities in Ghana, since their presence in the country was first reported by Ratnadass et al. (2003).
Ratnadass and Ajayi (1995b) linked head bugs to compact headed sorghum types. Ajayi et al. (2001) established that head bugs were less abundant on landraces than on improved cultivars. This assertion was based on the fact that most landraces have long glumes, which cover the grains until the endosperm becomes hard enough to resist oviposition and feeding by head bugs. Many improved varieties of sorghum, for example the Caudatum types, have compact panicles, which create a relatively stable and humid micro-climate for the bug (Sharma et al., 1994; Ratnadass and Ajayi, 1995; Kudadjie et al., 2008). Head bugs, thus pose a major threat to increased sorghum production in Africa, since the damage they inflict on the grains predisposes them to mould infection (Marley and Ajayi, 1999).

Grain moulds are of limited importance in local sorghum varieties, which normally mature towards the end of the growing period when the risk of mould-conducive humid conditions is low. However, the disease has become a major problem with the introduction of early maturing compact-headed genotypes that fill grains during periods of relatively high rainfall (Williams and McDonald, 1983; Thomas, 1992). Infected seeds of low quality are not good for brewing local beer, 'pito', possess low food value and have poor germination quality.

Ratnadass et al. (1995a) demonstrated a relationship between head-bug infestation and 
grain mould infection, during experiments at the Institut d'économie Rurale (IER) at Sotuba in Mali. Bandyopadhyay et al. (2000) stated that while grain mould fungi may penetrate sorghum grain directly under high humidity conditions, infection by these fungi can be aided by biotic factors especially insects.

Kudadjie et al. (2004) noted that in the Upper East Region of Ghana, three sorghum varieties, namely Naga white, Framida and Kapaala, from the savannah Agricultural Research Institute (SARI) were introduced to farmers. A number of reasons, however, discouraged farmers from growing these improved varieties. Although Kapaala was high yielding among the sorghum cultivars introduced, to farmers' its major problem was its compact headed nature which made it a favourable host for head bugs leading to severe damage, thus affecting the quality of the grains. Kudadjie et al. (2004) indicated that breeders were already aware of the problem associated with Kapaala's susceptibility to head bug infestation and a hybridisation programme was being carried out to open up its panicle. The Savannah Agricultural Research Institute initiated a breeding programme and developed six open panicle derivatives of Kapaala that will be both high yielding and tolerant to head bug infestation and damage. The objective of this study was to investigate the effect of head bug infestation and mould infection on the grain quality of the breeding lines in the field.

\section{MATERIALS AND METHODS}

Experimental sites. A multi-locational study was conducted in Savannah Agriculture Research Institute (SARI), at Nyankpala, Damongo and Manga sites. The Nyankpala and the Damongo sites lie in the Guinea savannah zone of Northern Ghana about $124 \mathrm{Km}$ apart. Nyankpala is located on latitude $9^{\circ} 25^{\prime \prime} 41^{\prime} \mathrm{N}$ and $0^{\circ} 58^{\prime \prime} 42^{\prime} \mathrm{W}$ and at altitude $183 \mathrm{~m}$ above sea level. The mean annual rainfall of Nyankpala is about $1000 \mathrm{~mm}$ and the mean annual temperature is $28.3^{\circ} \mathrm{C}$. Damongo lies on
Latitude $8^{\circ} 32^{\prime}$ and $10^{\circ} 2^{\prime} \mathrm{N}$ and longitude $1^{\circ}$ $5^{\prime}$ and $2^{\circ} 58^{\prime} \mathrm{W}$ and experiences an annual rainfall of $1144 \mathrm{~mm}$ and a mean annual temperature of $27^{\circ} \mathrm{C}$.

Manga, is located on latitude $10^{\circ} 15^{\prime \prime}$ and $11^{\circ} 10^{\prime \prime} \mathrm{N}$ and $0^{\circ}$ and $1^{\circ} 0^{\prime \prime} \mathrm{W}$. It lies in the semi-arid part of the Volta Basin, falling in the transitional zone of the Sudan savannah Agroecological Zone. The area is characterised by a uni-modal rainfall pattern with a mean annual rainfall of $950 \mathrm{~mm}$.

The vegetation of these locations, except Damongo, comprises scattered trees and shrubs with grass under-growths. Due to increasing population; coupled with low crop yields, fallows are now almost non-existent at all three locations

Experimental materials. The plant materials used for this study (Table 1) were obtained from the Savannah Agriculture Research Institute in Ghana. They consisted of two parental checks and six $F_{8}$ derivatives with varying panicle shapes obtained by repeated backcrossing to Kapaala as the recurrent parent. The aim was to maintain the good qualities and high yield of Kapaala; while opening the panicle shape for reduced head bug infestation.

Experimental design and crop management. The lines were sown in a randomised complete block design (RCBD), with four replications. Plot size consisted of 6 ridges, which were $5 \mathrm{~m}$ long and $0.75 \mathrm{~m}$ apart.

Four seeds were planted per hill at $0.30 \mathrm{~m}$ spacing on ridges, and were thinned to two plants per hill, two weeks after emergence. NPK 15: 15: 15 fertiliser was applied at 250 $\mathrm{kg} \mathrm{ha}^{-1}$ two weeks after sowing and sulphate of ammonia $150 \mathrm{~kg} \mathrm{ha}^{-1}$, two weeks after the first fertiliser application. Weeds were controlled by hand weeding at three and five weeks after crop emergence at all locations.

Head bug field infestation and grain damage. To determine Eurystylus oldi 
TABLE 1. Description of experimental materials (sorghum) used in the study, sourced from the Savanna Agriculture Research Institute in Ghana

\begin{tabular}{ll} 
Lines & Description \\
\hline Kadaga & Grain colour is brown with black glumes. Average height is $3.0 \mathrm{~m}$. Panicle is very loose \\
Kapaala & Grain colour is white. Has an average height of $2.5 \mathrm{~m}$. Plant type is tan and panicle is compact \\
SARSORG-MBG-2011-4 & $\begin{array}{l}\mathrm{F}_{8} \text { derivative of Kapaala and Kadaga crosses. It is a medium maturing line. The plant type is tan, with white grain covered with brown glumes. } \\
\text { Panicle type is semi-loose }\end{array}$
\end{tabular}

SARSORG-MRG-2011-3 $\quad \mathrm{F}_{8}$ derivative of Kapaala and Kadaga crosses. It is a medium maturing line. The plant type is tan, with white grain covered with red glumes. Panicle type is semi-loose

SARSORG-SBG-2011-5 $\quad \mathrm{F}_{8}$ derivative of Kapaala and Kadaga crosses. It is a short maturing line. The plant type is tan, with white grain covered with brown glumes. Panicle type is very loose

SARSORG-SRG-2011-6 $\quad \mathrm{F}_{8}$ derivative of Kapaala and Kadaga crosses. It is a short maturing line. The plant type is tan, with white grain covered with red glumes. Panicle type is semi-loose

SARSORG-TBG-2011-2 $\quad \mathrm{F}_{8}$ derivative of Kapaala and Kadaga crosses. It is a tall maturing line. The plant type is tan, with white grain covered with brown glumes. Panicle type is semi-loose

SARSORG-TRG-2011-1 $\quad \mathrm{F}_{8}$ derivative of Kapaala and Kadaga crosses. It is a tall maturing line. The plant type is tan, with white grain covered with red glumes. Panicle type is loose with drooping primary branches

Sorghum Improvement Section - Savannah Agriculture Research Institute, Ghana 
infestation and grain damage scores, bug population was assessed at the dough stage; three weeks after flowering. The number of head bugs was obtained from the ten tagged plants by lowering the panicle for each plant into a polyethylene bag large enough to accommodate the panicle and shaken vigorously by hand (Ratnadass et al., 2003). The bagged samples were preserved at $0^{\circ} \mathrm{C}$. Samples were later defrosted in the laboratory for one hour and inspected in small portions in a glass petri dish, to facilitate counting of the head bugs.

Feeding damage was scored on a 1 to 9 rating scale (Sharma et al., 1997); where $1=$ all grains fully developed with a few feeding punctures; 2 = grain fully developed, with feeding punctures; 3 = grains showing slight tanning or browning; $4=$ most grains with feeding punctures, and a few showing slight shriveling; 5 = grains showing slight shriveling and browning; $6=$ grains showing more than $50 \%$ shriveling and turning brown or tanned; $7=$ most of the grain highly shriveled and dark brown coloration; $8=$ grain highly shriveled and slightly visible outside the glumes; and 9 $=$ most of the grains highly shriveled and slightly visible outside the glumes. Correlation between head bug infestation and damage scores was then determined using Pearson's correlations analysis.

Mould infection. Grain mould scores were taken twice, first in the field at physiological maturity where panicle grain mould rating (PGMR) was scored on a 1 to 5 scale where, $1=$ grains on panicle has no mould, $2=1-10$ $\%$ of grains on panicle has mould, $3=11-25$ $\%$ of grains on panicle has mould, $4=26-50$ $\%$ of grains on panicle has mould, and $5>50$ $\%$ of grains on panicle has mould in the field.

The second scoring was done after harvesting, manual threshing by putting them into a mini-sacks and beaten with stick until all grains were removed from the panicle, and conventional sun drying for about $12 \mathrm{hr}$ three days before storage. Twenty grammes of threshed grain sample from the bulk of the 10 panicles was collected per plot, and spread evenly in petri dishes. The samples were then scored for threshed grain mould rating (TGMR) using the above -1 to 5 severity rating (Thakur et al., 2006). Correlation between head bug damage scores and PGMR and TGMR were then determined.

Infection by mould. The test to determine the mycoflora associated with sorghum seed was undertaken in the Plant Pathology Laboratory at the University of Ghana. Petri dishes with cotton-blotting paper were prepared under aseptic conditions. The lower lids were lined with a thin layer of absorbent cotton, followed by two layers of blotter paper. The entire assembly was placed in a stainless steel sterilising container, and sterilised in an autoclave at $121^{\circ} \mathrm{C}$ and 15 PSI for $15 \mathrm{~min}$. The cotton-blotting paper was then wetted with $15 \mathrm{ml}$ of distilled water, in a petri dish, to serve as a humidity chamber.

Twenty five grains from each harvested plot were surface sterilised in $1 \%$ sodium hypochlorite, for three minutes, and rinsed with three washes in sterile distilled water. The grain samples were transferred onto the sterilised Petri dish humidity chambers, under aseptic conditions. The plates were then incubated at $28 \pm 1^{\circ} \mathrm{C}$ for 5 days; and seeds were examined for the presence of fungi.

For easy identification of the various fungal colonies associated with seeds of the breeding lines, slides of the fruiting structures of the fungi were prepared with the help of a sterilised incubating needle, and examined under a compound microscope. The various fungi species were then identified on the basis of morphology of mycelia, conidia and fruiting structure as described by Navi et al. (1999) and Barnett and Hunter (2006). The relative frequency of occurrence of particular fungi was calculated using the formula of Ghiasian et al. (2004).

Grain quality. High performing breeding lines were selected by ranking the lines' in terms of head bug and mould damage ratings (PGMR 
and TGMR). Breeding lines with low average values were considered more desirable.

Climatic data. Data on temperature and rainfall were obtained from weather stations established by SARI at the three locations of this study.

Data analysis. Prior to analysis, head bug counts were square root transformed; whereas percentage fungi occurrence was arcsine transformed. Data were subjected to analysis of variance for each parameter using the GenStat $12^{\text {th }}$ edition. Treatment differences were compared using the Least Significant Difference (LSD) at $\mathrm{P}<0.05$ level of probability. Data were also subjected to correlation analyses on locational basis to elucidate the relationship among the selection indices.

\section{RESULTS AND DISCUSSIONS}

Head bug infestation. The number of head bugs per 10 panicles observed at Manga,
Damongo and Nyankpala is presented in Figure 1. Highly significant $(\mathrm{P}<0.01)$ differences were observed among the breeding lines at Manga and Damongo. At Manga, assessment was done in September, when the temperatures ranged between $22.3-31.1{ }^{\circ} \mathrm{C}$. The lowest head bug population (9.5 per 10 panicles) was recorded on SARSORG-TRG-2011-1, while Kapaala, Kadaga and SARSORG-TBG-20112 recorded very high bug populations of 15.2 , 14.7 and 12.2, respectively which did not differ significantly from each other (Fig. 1). At Damongo, bug population assessment was done in late August when minimum and maximum temperatures ranged between 21.5 and $30.3^{\circ} \mathrm{C}$. The highest and lowest numbers of bugs were recorded on SARSORG-TBG2011-2 (3.9) and Kadaga (1.6) (Fig. 1).

Assessment at Nyankpala was done in September with temperatures ranging between $23.1-30.5^{\circ} \mathrm{C}$. Significant $(\mathrm{P}<0.05)$ differences among the head bug populations were observed for the breeding lines evaluated. The bug numbers ranged from 2.3 (Kadaga) to 5.0 (Kapaala) per 10 panicles (Fig. 1).

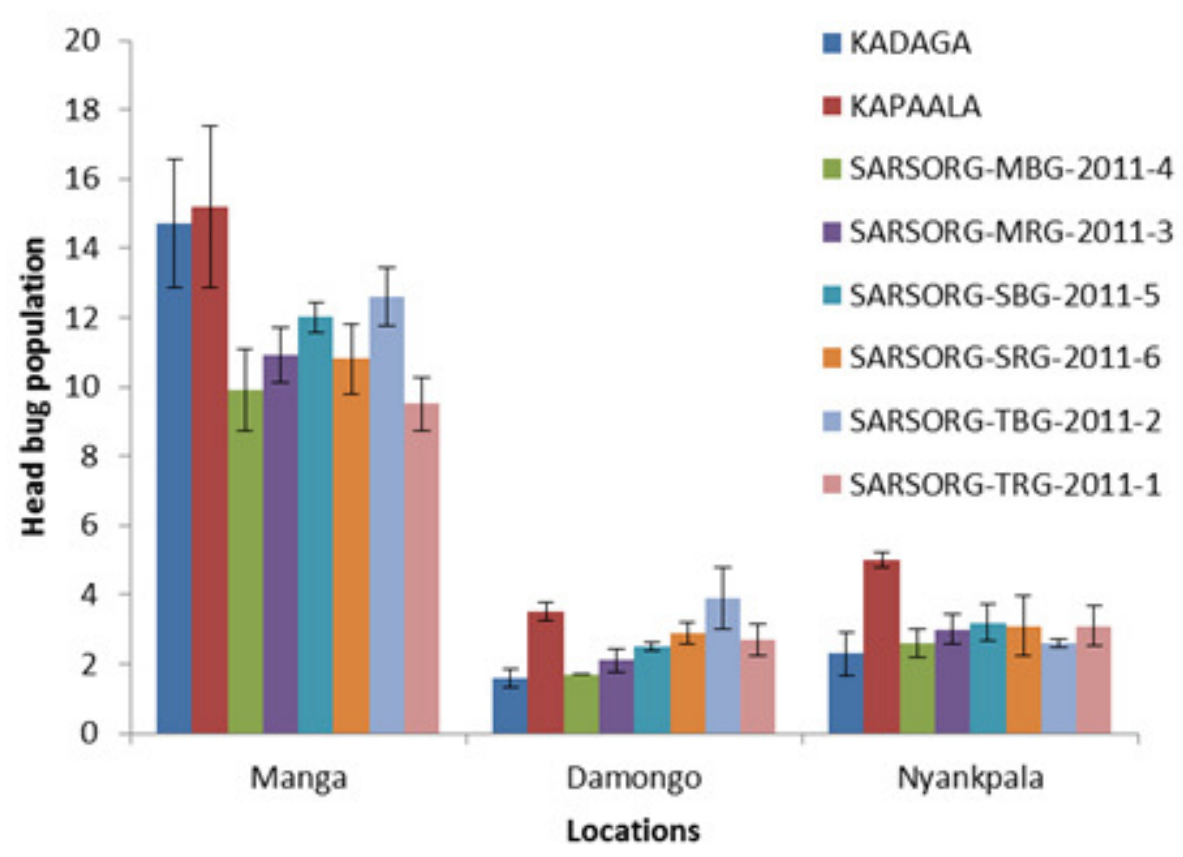

Figure 1. Head bug population on eight sorghum lines grown at Manga, Damongo and Nyankpala in Ghana. 
A study of the insect fauna sampled across all three locations; however, revealed that Manga supported the largest head bug population density, followed by Nyankpala (Fig. 1). The high level of population build-up observed in Manga may be attributed to the fact that the location and its surrounding communities support large scale production of the host plant. The population of bugs on individual breeding lines also revealed that apart from Kapaala, which provided a better lodging for the highest bug number in Manga and Nyankpala, the rest of the open-panicle derivatives equally harboured significantly higher numbers of bugs.

While head bugs have been reported to express preference for compact headed sorghum lines for favouring their feeding activities, survival, development and fecundity (Sharma et al., 1994; Showemimo et al., 2011), the huge bug numbers observed in Kadaga and the rest of the open panicle derivatives at Manga might be linked to head bug population exceeding the threshold for resistance among the lines and, hence did not reflect in the differences in insect numbers recorded.

The economic threshold of head bugs on sorghum has been reported to vary from 4 (Hiremath, 1981) to 15 bugs per panicle (Natarajan and Sundarbabu, 1988). That notwithstanding, high numbers exceeding 200 bugs per panicle have also been reported (Hiremath, 1995). The very loose and slightly drooping seed primary branches of Kadaga which closes up when the head drops may perhaps aid in providing a favourable lodging for the bugs.

Head bug damage. Highly significant $(\mathrm{P}<0.01)$ differences among the breeding lines for head bug damage were observed at Manga and Damongo, but not at Nyankpala (Fig. 2). At Manga, Kapaala suffered the most damage

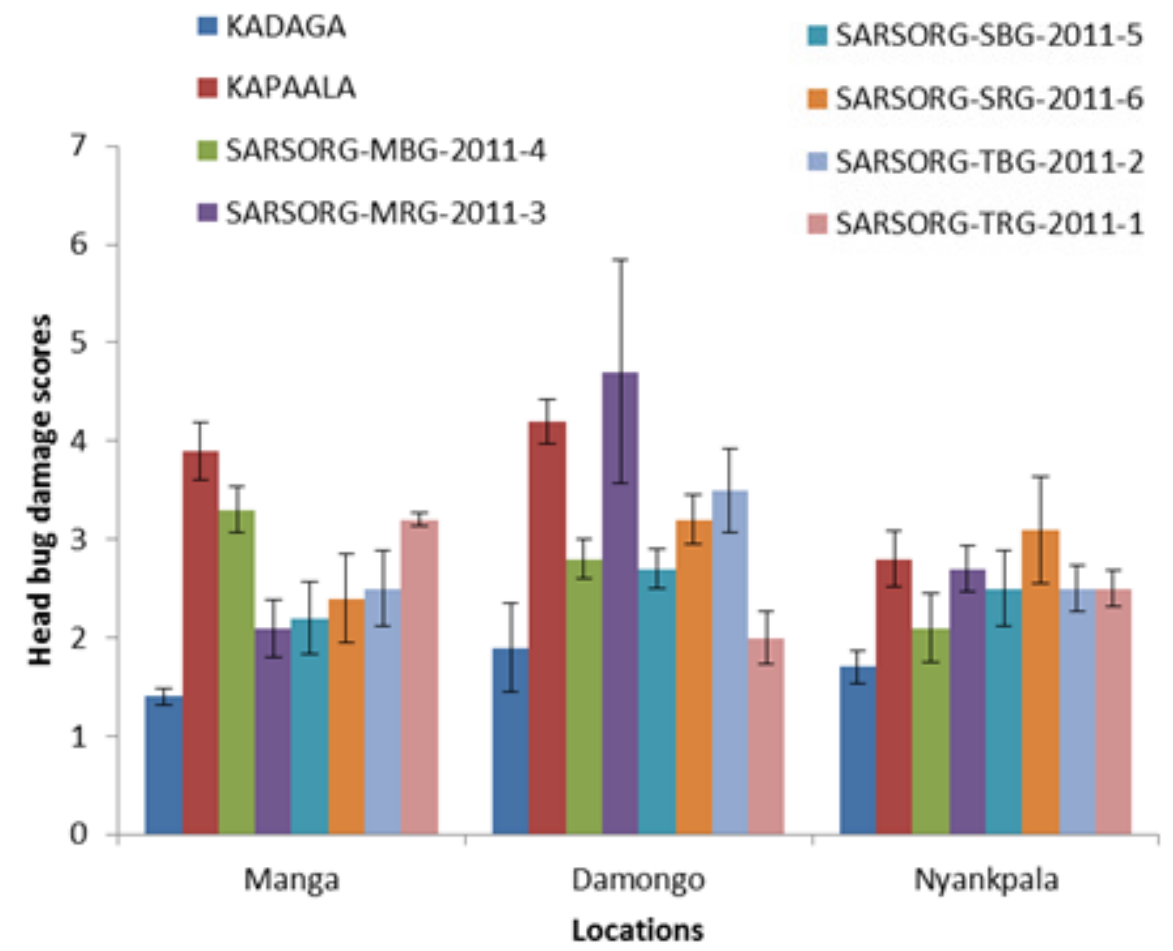

Figure 2. Head bug damage of eight sorghum lines grown at Manga, Damongo and Nyankpala in Ghana. 
with a score of 3.9. However, this was not significantly different from the damage scores recorded by SARSORG-MBG-2011-4 (3.3) and SARSORG-TRG-2011-1 (3.2). The least damaged line was Kadaga with mean damage score of 1.4 .

At Damongo, SARSORG-MRG-2011-3 and Kapaala recorded the highest mean damage scores of 4.7 and 4.2, respectively (Fig. 2). The least damaged lines were Kadaga and SARSORG-TRG-2011-1 each obtaining mean damage scores of 1.9 and 2.0, respectively.

Although the breeding lines showed no significant differences for damage at Nyankpala, damage ratings ranged from 1.7 to 3.1 and were recorded by Kadaga and Sarsorg-srg-2011-6, respectively.

The compact head shape of Kapaala has been reported by Ratnadass and Ajayi (1995b) to favour head bug infestation and damage; whereas the very loose head shape of Kadaga, according to ICRISAT (1995), supports lower bug numbers hence suffer less grain damage. This could be the reason why Kapaala did not only provide better lodging for the head bugs across locations, but also favoured higher grain damage.

Mould infection. Assessment of panicle grain mould rating (PGMR) at the three locations revealed highly significant $(\mathrm{P}<0.01)$ differences among the breeding lines (Table 2). At Manga, although the derivative SARSORG-TRG-2011-1 obtained a higher rating of 2.4, it was not significantly different from the rest of the lines apart from Kadaga, SARSORG-MRG-2011-3 and Kapaala which recorded 1.0, 1.8 and 3.1, respectively.

The lowest and highest panicle mould infection scores at Damongo were recorded on the two parental checks, Kadaga and Kapaala with mean scores of 1.2 and 3.5, respectively. Some of the derivatives also recorded relatively high mould infection scores. SARSORG-MRG-2011-3 for instance recorded a high score of 3.0, but did not vary significantly from the 3.5 obtained on Kapaala

Panicle grain mould ratings (PGMR) at Nyankpala ranged from 1.2 to 2.5 (Table 2). The resistant and susceptible parents, Kadaga

TABLE 2. Scores of grain mould infection on eight genotypes of sorghum at physiological maturity (PGMR) and on threshed grain (TGMR) across three locations in Ghana

\begin{tabular}{|c|c|c|c|c|c|c|c|c|}
\hline \multirow[t]{2}{*}{ Genotypes } & \multicolumn{4}{|c|}{ PGMR } & \multicolumn{4}{|c|}{ TGMR } \\
\hline & Mga & Dgo & Nkla & Mean & Mga & Dgo & Nkla & Mean \\
\hline Kadaga (res. Check) & 1.0 & 1.2 & 1.2 & 1.1 & 1.0 & 1.0 & 1.0 & 1.0 \\
\hline Kapaala (sus. Check) & 3.1 & 3.5 & 2.5 & 3.0 & 3.5 & 3.0 & 3.0 & 3.2 \\
\hline Sarsorg-mbg-2011-4 & 2.1 & 2.4 & 1.9 & 2.1 & 2.8 & 3.8 & 2.3 & 2.9 \\
\hline Sarsorg-mrg-2011-3 & 1.8 & 3.0 & 1.9 & 2.2 & 2.8 & 4.0 & 2.3 & 3.0 \\
\hline Sarsorg-sbg-2011-5 & 2.1 & 2.4 & 2.3 & 2.3 & 3.3 & 4.0 & 3.0 & 3.4 \\
\hline Sarsorg-srg-2011-6 & 2.0 & 2.6 & 2.4 & 2.3 & 2.3 & 3.5 & 3.3 & 3.0 \\
\hline Sarsorg-tbg-2011-2 & 2.1 & 2.7 & 2.2 & 2.4 & 3.5 & 4.3 & 3.0 & 3.6 \\
\hline Sarsorg-trg-2011-1 & 2.4 & 2.1 & 2.2 & 2.2 & 2.5 & 3.0 & 2.3 & 2.6 \\
\hline Mean & 2.1 & 2.5 & 2.1 & 2.2 & 2.7 & 3.3 & 2.5 & 2.8 \\
\hline $\mathrm{SE}(\mathrm{m}) \pm$ & 0.2 & 0.2 & 0.2 & & 0.3 & 0.3 & 0.4 & \\
\hline $\mathrm{LSD}_{0.05}$ & 0.6 & 0.7 & 0.5 & & 0.8 & 0.8 & 1.1 & \\
\hline CV $(\%)$ & 18.5 & 18.6 & 16.9 & & 21.3 & 16.0 & 29.3 & \\
\hline
\end{tabular}

Dgo $=$ Damongo, $\mathrm{Mga}=$ Manga, Nkla $=$ Nyankpala res. Check $=$ resistant check, sus. Check $=$ susceptible check 
and Kapaala showed the lowest and highest ratings of 1.2 and 2.5, respectively. The derivative with the highest rating was SARSORG-SRG-2011-6 (2.4).

The high panicle grain mould ratings (PGMR) values obtained at Damongo may be the direct influence of rainfall $(134.7 \mathrm{~mm})$ recorded in September, preceding harvest. The minimum level of PGMR observed on the derivatives, including Kadaga corroborates the assertions of Khaing et al. (2013) that openpanicle cultivars of sorghum lines serve as an adaptive trait to allow quick drying of panicles in high-humidity environments.

Threshed grain mould rating (TGMR) also showed highly significant $(\mathrm{P}<0.01)$ differences across the three locations (Table 2). At Manga, threshed grain mould ratings varied from 1.0 to 3. However, Kapaala SARSORG-TBG-2011-2 and SARSORGSBG-2011-5 recorded very high ratings of 3.5, 3.5 and 3.3 , respectively which did not differ from each other

Threshed grain mould ratings (TGMR) at Damongo ranged from 1.0 to 4.3. The line with the most TGMR was SARSORG-TBG2011-2 (4.3) followed by SARSORG-MRG2011-3 and SARSORG-SBG-2011-5, both recording a score of 4.0. The line with the least TGMR was Kadaga with a score of 1.0

At Nyankpala, SARSORG-SRG-2011-6 recorded the highest TGMR of 3.3 which varied from the 1.0 obtained by Kadaga but not Kapaala which recorded a rating of 3.0. The overall TGMR scores from all three locations showed that SARSORG-TBG-20112 (3.6) and SARSORG-SBG-2011-5 (3.4) were the most damaged breeding lines.

Based on these results and other by Thakur et al. (2007), one can suggest that scoring for grain mould severity at physiological maturity in the field was more reliable than on threshed grain, since prevailing humidity conditions may influence threshed grain mould ratings (TGMR) data which is usually taken several days after panicle grain mould ratings (PGMR).

Correlation of traits. At Manga, panicle grain mould rating (PGMR) correlated positively ( $\mathrm{r}$ $=0.91 ; \mathrm{P}<0.001)$ with head bug damage (Table 3). There was also a positive correlation $(\mathrm{r}=0.78 ; \mathrm{P}<0.02)$ between PGMR and TGMR. On the contrary, head bug population and head bug damage produced a negative correlation $r=-0.09(\mathrm{P}>0.82$ (Table 3). At Damongo, head bug damage and PGMR produced a significant $(\mathrm{r}=0.87 ; \mathrm{P}<0.01)$ positive correlation. On the other hand, head bug population and head bug damage did not produce a significant correlation $(r=0.385$; $P>0.347)$. There was also no significant correlation between PGMR and TGMR (Table 4). At Nyankpala a significant positive correlation $(r=0.85 ; P<0.01)$ between head bug damage and PGMR, and between head bug damage and TGMR $(r=0.85 ; \mathrm{P}<0.01)$ were recorded. Unlike at Damongo, correlation between PGMR and TGMR was highly significant $(r=0.95 ; \mathrm{P}<0.001)$ (Table 5).

TABLE 3. Correlation coefficient among agronomic parameters of sorghum lines evaluated at Manga in Ghana

\begin{tabular}{|c|c|c|c|c|c|c|}
\hline & $\begin{array}{l}\text { Grain } \\
\text { yield }\end{array}$ & $\begin{array}{c}\text { Panicle } \\
\text { weight }\end{array}$ & $\begin{array}{l}\text { Bug } \\
\text { population }\end{array}$ & Bug damage & PGMR & TGMR \\
\hline Grain yield & 1.000 & & & & & \\
\hline Panicle weight & $0.929 * *$ & 1.000 & & & & \\
\hline Bug population & -0.438 & -0.455 & 1.000 & & & \\
\hline Bug damage & $0.662^{\mathrm{ns}}$ & $0.447^{\mathrm{ns}}$ & -0.092 & 1.000 & & \\
\hline PGMR & $0.747 *$ & $0.508^{\mathrm{ns}}$ & -0.009 & $0.913 * *$ & 1.000 & \\
\hline TGMR & $0.555^{\mathrm{ns}}$ & $0.256^{\mathrm{ns}}$ & -0.056 & $0.597^{\mathrm{ns}}$ & $0.778^{*}$ & 1.000 \\
\hline
\end{tabular}

$* *$ indicates significance at $\mathrm{P}<0.01 ; *=$ significance at $\mathrm{P}<0.05$ and $\mathrm{ns}=$ non-significance at $\mathrm{P}<0.05$ 
TABLE 4. Correlation coefficient among agronomic parameters of sorghum lines evaluated at Damongo in Ghana

\begin{tabular}{lllcccc}
\hline & $\begin{array}{l}\text { Grain } \\
\text { yield }\end{array}$ & $\begin{array}{c}\text { Panicle } \\
\text { weight }\end{array}$ & $\begin{array}{c}\text { Bug } \\
\text { population }\end{array}$ & Bug damage & PGMR & TGMR \\
\hline Grain yield & 1.000 & & & & & \\
Panicle weight & $0.973^{* *}$ & 1.000 & & & & \\
Bug population & $0.296^{\mathrm{ns}}$ & $0.218^{\mathrm{ns}}$ & 1.000 & & & \\
Bug damage & $0.172^{\mathrm{ns}}$ & $0.069^{\mathrm{ns}}$ & $0.378^{\mathrm{ns}}$ & 1.000 & & \\
PGMR & $0.341^{\mathrm{ns}}$ & $0.185^{\mathrm{ns}}$ & $0.598^{\mathrm{ns}}$ & $0.873^{* *}$ & 1.000 & \\
TGMR & $0.071^{\mathrm{ns}}$ & $0.017^{\mathrm{ns}}$ & $0.414^{\mathrm{ns}}$ & $0.532^{\mathrm{ns}}$ & $0.659^{\mathrm{ns}}$ & 1.000 \\
\hline
\end{tabular}

** = indicates significance at $\mathrm{P}<0.01$; and $\mathrm{ns}=$ non-significance at $\mathrm{P}<0.05$

TABLE 5. Correlation coefficient among agronomic parameters of sorghum lines evaluated at Nyankpala in Ghana

\begin{tabular}{|c|c|c|c|c|c|c|}
\hline & $\begin{array}{l}\text { Grain } \\
\text { yield }\end{array}$ & $\begin{array}{l}\text { Panicle } \\
\text { weight }\end{array}$ & $\begin{array}{l}\text { Bug } \\
\text { population }\end{array}$ & Bug damage & PGMR & TGMR \\
\hline Grain yield & 1.000 & & & & & \\
\hline Panicle weight & $0.971 * *$ & 1.000 & & & & \\
\hline Bug population & $-0.473^{\mathrm{ns}}$ & $-0.522^{\mathrm{ns}}$ & 1.000 & & & \\
\hline Bug damage & $-0.094^{\mathrm{ns}}$ & $-0.200^{\mathrm{ns}}$ & $0.561^{\mathrm{ns}}$ & 1.000 & & \\
\hline PGMR & $-0.180^{\mathrm{ns}}$ & $-0.312^{\mathrm{ns}}$ & $0.659 \mathrm{~ns}$ & $0.852 * *$ & 1.000 & \\
\hline TGMR & $-0.281^{\mathrm{ns}}$ & $-0.414^{\mathrm{ns}}$ & $0.489^{\mathrm{ns}}$ & $0.851 * *$ & $0.947 * *$ & 1.000 \\
\hline
\end{tabular}

$* *$ indicates significance at $\mathrm{P}<0.01 ;$ and $\mathrm{ns}=$ non-significance at $\mathrm{P}<0.05$

The highly significant correlations between head bug damage and PGMR identified across the three locations is a clear indication of the significant roles head bug damage plays in grain mould infection, an emphasis which was also strongly advocated by Sharma et al. (2000). Furthermore, the non-significant correlation between head bug population and damage recorded across the three locations suggests that high bug numbers are not a prerequisite for significant level of grain damage to occur; which is in line with the findings of Harris (1995). For instance, a field visit at noon at Manga revealed high bug presence in both compact and semi-compact panicles; and some bugs hiding underneath the leaves to avoid direct contact with the hot sun. This phenomenon thus suggests that the presence of bugs do not necessarily result in sever feeding damage although some level of feeding will occur.
Despite showing a significant correlation at Nyankpala $(r=0.85)$, the relationship between head bug damage and TGMR was not significant at Manga $(r=0.59)$ and Damongo $(r=0.53)$. These low correlations may suggest that in the absence of high humidity and suitable temperature, as major abiotic factors, bug damage alone may not impose high level of mould infection on stored grains. The significant relationship observed between PGMR and TGMR at Manga and Nyankpala, but not at Damongo suggests that scoring for grain mould severity at physiological maturity in the field was more reliable than on threshed grain since prevailing humidity conditions could influence TGMR data, which is usually taken several days after PGMR (Thakur et al., 2007). Thus, for all grain mould screening, the PGMR scores alone are enough to set apart lines into resistant and susceptible classes (Thakur et al., 2007). 
Fungal profiles. A total of six fungal genera, namely, Aspergillus, Curvularia, Fusarium, Thielaviopsis, Exserohilum and Rhizopus, were isolated from the infected seeds at Manga (Table 6). Curvularia recorded the highest percentage frequency of isolation $(31.6 \%)$, followed by Fusarium (22.3\%). Other fungal species with lesser frequencies identified included Exserohilum (2.4\%) and Rhizopus $(1.6 \%)$ (Table 6). A total of five fungi genera were identified at Damongo. These included Fusarium (29.6\%) and Curvularia (23.6\%) producing the highest scores with Epicoccum (13.6) having the least frequency (Table 6). Curvularia was the dominant fungus isolated at Nyankpala with a frequency of $31.4 \%$ followed by Fusarium (27.6 \%) (Table 6).

Field assessment for grain mould infection identified that mould contamination was widespread in the three locations (Table 6). The high mould incidence might be due to the occurrence of rainfall and favourable temperatures days preceding harvest which creates the ambient conditions for fungal growth. This high level of grain contamination could result in severe yield and quality losses as was indicated by Das and Govardhan (2015).

An earlier study by Nutsugah et al. (2003) identified $P$. sorghina and Fusarium moniliforme sensu lato as the most frequently isolated seed-borne fungi associated with

TABLE 6. Frequency of occurrence of fungi isolated from seeds of eight sorghum lines in Ghana

\begin{tabular}{lrrr}
\hline Fungi & \multicolumn{3}{c}{ Frequency of isolation from seeds (\%) } \\
\cline { 2 - 4 } & Manga & Damongo & Nyankpala \\
\hline Curvularia & 31.6 & 23.6 & 31.4 \\
Fusarium & 22.3 & 29.6 & 27.6 \\
Rhizopus & 1.6 & - & - \\
Thielaviopsis & 20.3 & - & 20.1 \\
Aspergillus & 21.8 & 16.0 & - \\
Exserohilum & 2.4 & - & 20.9 \\
Epicoccum & - & 13.6 & - \\
Mucor & - & 17.2 & - \\
\hline
\end{tabular}

sorghum. The high presence of these fungi, especially Curvularia and Fusarium, corroborates the findings of Forbes et al. (1992), Singh and Bandyopadhyay (2000) and Prom et al. (2011) who also identified Curvularia as the major pathogen responsible for grain mould throughout sorghum producing regions. Sharma et al. (2010), on the other hand also, cited Fusarium as the dominant fungi in sorghum caryopsis

Grain quality. The derivatives recorded lower panicle grain mould ratings (PGMR) $(<2.5)$; while more than 3.0 was obtained for Kapaala at Manga (Table 7). Ranking the breeding lines for grain quality suggests that the breeding lines vary significantly. The average values depicted that SARSORG-MRG-2011-3, SARSORGSRG-2011-6 and SARSORG-SBG-2011-5 were superior. The least desired line was the commercial susceptible parent, Kapaala, and three derivatives, SARSORG-TRG-2011-1, SARSORG-TBG-2011-2 and SARSORGMRG-2011-3.

The breeding lines evaluated at Damongo recorded higher PGMR (>2.5), except for SARSORG-TRG-2011-1 (2.1), SARSORGSBG-2011-5 and SARSORG-MBG-2011-4, both rating 2.4 (Table 8 ). Kapaala on the other hand recorded a high mean PGMR of 3.5. These reflect the direct influence of rainfall $(134.7 \mathrm{~mm})$ recorded in September, preceding harvest.

When sorghum lines were ranked on the bases of grain quality, Kadaga (resistant parent) again emerged the best. The following lines, SARSORG-TRG-2011-1, SARSORG-MBG2011-4 and SARSORG-SBG-2011-5 were the best 3 derivatives for desired qualitative traits. The least desired lines were SARSORG-TBG2011-2, SARSORG-MRG-2011-3 and the susceptible parent, Kapaala (Table 8).

At Nyankpala, the derivatives recorded lower mean PGMR $(<2.5)$ (Table 9). For the average values based on the qualitative performance of the breeding lines using bug damage, PGMR and TGMR showed Kadaga 
TABLE 7. Ranking of the performances of sorghum lines for quality using head bug and mould damage at Manga in Ghana

\begin{tabular}{lcccccccc}
\hline Lines & $\begin{array}{c}\text { Bug } \\
\text { damage }\end{array}$ & Rank & PGMR & Rank & TGMR & $\begin{array}{c}\text { Rank } \\
\begin{array}{c}\text { Rank } \\
\text { sum }\end{array}\end{array} \begin{array}{c}\text { Average } \\
\text { value }\end{array}$ \\
\hline Kadaga & 1.4 & 1 & 1.0 & 1 & 1.0 & 1 & 3 & 1 \\
Kapaala & 3.9 & 8 & 3.1 & 8 & 3.5 & 7 & 23 & 8 \\
SARSORG-MBG-2011-4 & 3.3 & 7 & 2.1 & 4 & 2.8 & 4 & 15 & 5 \\
SARSORG-MRG-2011-3 & 2.1 & 2 & 1.8 & 2 & 2.8 & 4 & 8 & 3 \\
SARSORG-SBG-2011-5 & 2.2 & 3 & 2.1 & 4 & 3.3 & 6 & 13 & 4 \\
SARSORG-SRG-2011-6 & 2.4 & 4 & 2.0 & 3 & 2.3 & 2 & 9 & 3 \\
SARSORG-TBG-2011-2 & 2.5 & 5 & 2.1 & 4 & 3.5 & 7 & 16 & 5 \\
SARSORG-TRG-2011-1 & 3.2 & 6 & 2.4 & 7 & 2.5 & 3 & 16 & 5 \\
\hline
\end{tabular}

Breeding lines with less average values are considered more preferred

TABLE 8. Ranking of the performances of sorghum lines for quality using head bug and mould damage at Damongo in Ghana

\begin{tabular}{lcccccccc}
\hline Lines & $\begin{array}{c}\text { Bug } \\
\text { damage }\end{array}$ & Rank & PGMR & Rank & TGMR & Rank & $\begin{array}{c}\text { Rank } \\
\text { sum }\end{array}$ & $\begin{array}{c}\text { Average } \\
\text { value }\end{array}$ \\
\hline Kadaga & 1.9 & 1 & 1.2 & 1 & 1.0 & 1 & 3 & 1 \\
Kapaala & 4.2 & 7 & 3.5 & 8 & 3.0 & 2 & 17 & 6 \\
SARSORG-MBG-2011-4 & 2.8 & 4 & 2.4 & 3 & 3.8 & 5 & 12 & 4 \\
SARSORG-MRG-2011-3 & 4.7 & 8 & 3.0 & 7 & 4.0 & 6 & 21 & 7 \\
SARSORG-SBG-2011-5 & 2.7 & 3 & 2.4 & 3 & 4.0 & 6 & 12 & 4 \\
SARSORG-SRG-2011-6 & 3.2 & 5 & 2.6 & 5 & 3.5 & 4 & 14 & 5 \\
SARSORG-TBG-2011-2 & 3.5 & 6 & 2.7 & 6 & 4.3 & 8 & 20 & 7 \\
SARSORG-TRG-2011-1 & 2.0 & 2 & 2.1 & 2 & 3.0 & 2 & 6 & 2 \\
\hline
\end{tabular}

Breeding lines with less average values are considered more preferred

TABLE 9. Ranking of the performances of sorghum lines for quality using head bug and mould damage at Nyankpala in Ghana

\begin{tabular}{lcccccccc}
\hline Lines & $\begin{array}{c}\text { Bug } \\
\text { damage }\end{array}$ & Rank & PGMR & Rank & TGMR & Rank $\begin{array}{c}\text { Rank } \\
\text { sum }\end{array}$ & $\begin{array}{c}\text { Average } \\
\text { value }\end{array}$ \\
\hline Kadaga & 1.7 & 1 & 1.2 & 1 & 1.0 & 1 & 3 & 1 \\
Kapaala & 2.8 & 7 & 2.5 & 8 & 3.0 & 5 & 20 & 7 \\
SARSORG-MBG-2011-4 & 2.1 & 2 & 1.9 & 2 & 2.3 & 2 & 6 & 2 \\
SARSORG-MRG-2011-3 & 2.7 & 6 & 1.9 & 2 & 2.3 & 2 & 10 & 3 \\
SARSORG-SBG-2011-5 & 2.5 & 3 & 2.3 & 6 & 3.0 & 5 & 14 & 5 \\
SARSORG-SRG-2011-6 & 3.1 & 8 & 2.4 & 7 & 3.3 & 8 & 23 & 8 \\
SARSORG-TBG-2011-2 & 2.5 & 3 & 2.2 & 4 & 3.0 & 5 & 12 & 4 \\
SARSORG-TRG-2011-1 & 2.5 & 3 & 2.2 & 4 & 2.3 & 2 & 9 & 3 \\
\hline
\end{tabular}

Breeding lines with less average values are considered more preferred 
as the superior parent with average value of

1. However, among the derivatives, the ranking was SARSORG-MBG-2011-4, SARSORG-MRG-2011-3 and SARSORGTRG-2011-1 as the lines with higher quality.

Crop production can be sustained when breeders do not only focus on yield, but also on other measurable traits such as insect and disease resistance (Sharma et al., 2005). Use of these traits in breeding will considerably increase breeding progress, compared to selection for yield alone (Edmeades et al., 1997). The low PGMR levels observed for the derivatives, including Kadaga, corroborates with the assertions of Khaing et al. (2013) that open-panicle cultivars of sorghum lines might have originated as an adaptive trait to allow quick drying of panicles in high-humidity environments in order to minimize insect and mould damage. The loose nature of the branches of the open panicles may allow those panicles with long primary branches to be tossed to and fro, especially as the wind blows thus disrupting oviposition activities of the head bugs.

The findings in the present study suggest that all three locations were considerably diverse from each other in terms of grain mould development due to their varying agroclimatic conditions such as rainfall and temperature during the growing season (Kibebe, 2015).

The performances of the following lines at Manga (SARSORG-MRG-2011-3, SAR SORG-SBG-2011-5 and SARSORG-SRG2011-6); (SARSORG-TRG-2011-1, SAR SORG-SBG-2011-5 and SARSORG-MBG2011-4) at Damongo; and (SARSORG-MBG2011-4, SARSORG-MRG-2011-3 and SARSORG-TRG-2011-1) at Nyankpala on the basis of their grain quality suggest they may possess some desirable traits for which they could be selected for further improvement at the specific environments.

\section{ACKNOWLEGEMENT}

The Savannah Agriculture Research Institute (SARI), in Ghana is acknowledged for providing the seeds for the study.

\section{REFERENCES}

Ajayi, O., Sharma, H.C., Tabo, R., Ratnadass, A. and Doumbia, Y.O. 2001. Incidence and distribution of sorghum head bug, Eurystylus oldi (Heteroptera: Miridae) in West and Central Africa. Insect Science and its Application 21:103-111.

Atokple, I.D.K. 1993. Nyankpala Agriculture Experiment Station Annual Report. Sorghum and Millet Section. pp. 75-80.

Bandyopadhyay, R., Butler, D.R., Chandrasekhar, A., Reddy, R.K. and Navi, S.S. 2000. Biology, epidemiology, and management of sorghum grain mould. In: Chandrashekar, A., Bandyopadhyay, R. and Hall, A.J. (Eds.), Technical and institutional options for sorghum grain mould management. Proceedings of an international consultation, 18-19 May. ICRISAT, Patancheru, India. Patancheru 502 324, Andhra Pradesh, India: International Crops Research Insitute for the Semi-Arid Tropics. pp. 34-71.

Barnett, H.L. and Hunter, B.B. 2006. Illustrated genera of imperfect fungi. 4th ed. Minnesota, USA: American Phytopathological Society Press.

Gerda MB, Christopher DV. 2007. Can GM sorghum impact Africa? Trends in Biotechnology 26:64 -69.

Das, I.K. and Govardhan, C. 2015. Minimization of floret infection by fungi causing grain mold in sorghum (Sorghum bicolor) through use of fungicides. Indian Phytopathology 68 (1): 67-72.

Forbes, G.A., Bandyopadhyay, R. and Garcia, G. 1992. A review of sorghum grain mould, 
In: de Milliano, W.A.J., Frederiksen, R.A., and Benston, G.D. (Eds.), Sorghum and Millets Diseases: A Second World Review. ICRISAT, Patancheru (A.P.), India. pp. 253-264.

Ghiasian, S.A., Kord-Bacheh P., Rezayat, S.M., Maghsood, A.H., and Taherkhani, H. 2004. Mycoflora of Iranian maize harvested in the main production areas in 2000 . Mycopathology 158 (1):113-121.

Harris, K.M. 1995. World review of recent research on panicle insect pests of sorghum and pearl millet. In: Nwanze, K.F. and Youm, O. (Eds.) Panicle insects of sorghum and pearl millet: Proceedings of an International Consultative Workshop, 4-7 October. pp. 7-25.

Hiremath, I.G. 1981. Studies on bionomics, crop loss and control of the sorghum ear head bug, Calocoris angustatus Lethiery (Ilemiptera: Miridac). PhD Thesis. University of Agricultural Sciences, Bangalore, Karnataka, India. 239pp.

Hiremath, I.G. 1995. Biology and population dynamics of sorghum head bug Calocoris angustatus in India. pp. 81-90. In: Panicle insect pests of sorghum and pearl millet: Proccedings of an International Consultative Workshop, 4-7 October, 1993, ICRISAT Sahelian Center. Niamey, Niger. Nwanze, K.F. and Yourn. O. (Eds.). Patancheru 502 324, Andhra Pradesh, India: International Crops Research Institute for the Semi-Arid Tropics.

International Crops Research Institute for the Semi-Arid Tropics. 1995. Annual report for 1994. Patancheru 502 324, Andhra Pradesh, India.

Khaing, P.W.H, Tariq, S. and Kazutoshi, O. 2013. Variation in inflorescence architecture associated with yield componentsin a sorghum germplasm. Plant Genetic Resources: Characterization and Utilization; 1-8doi:10.1017/S1479262 113000154

Kibebe, A.L. 2015. Genotype x environment interaction and stability of early maturing sorghum [Sorghum bicolor (L.) moench] genotypes in Ethiopia. M.sc. Thesis, Haramaya University, Haramaya, Ethiopia. pp. 1-35.

Kudadjie, C.Y., Struik, P.C., Richards, P. and Offei, S.K. 2004. Assessing production constraints, management and use of sorghum diversity in north-east Ghana: A diagnostic study. NJAS - Wageningen. Journal of Life Sciences 52:371-391.

Kudadjie-Freeman, C., Richards, P. and Paul C. S. 2008. Unlocking the potential of contract farming: Lessons from Ghana. Gatekeeper 139.

Marley, P.S. and Ajayi, O. 1999. Sorghum grain mould and the influence of head bug Eurystylus oldi in West and Central Africa. Journal of Sustainable Agriculture 13:3544.

Mishra, A., Hansen, J.W., Dingkuhn, M., Christian Baron, C., Traore, S.B., Ndiaye, O. and Ward, M.N. 2008. Sorghum yield prediction from seasonal rainfall forecasts in Burkina Faso. Agricultural and Forest Meteorology 148: 1798-1814.

Natarajan, N. and Sundarbabu, P.C. 1988. Economic injury level for sorghum earhead bug, Calocoris angustalus Lethiery in southern India. Insect Science and its Application 3:395-398.

Navi, S.S., Bandyopadhyay, R., Hall, A.J. and Bramel-Cox, P.J. 1999. A pictorial guide for the identification of mould fungi on sorghum grain. Information Bulletin No. 59. Patancheru 502 324, Andhra Pradesh, India: International Crops Research Institute for the Semi-Arid Tropics. pp. 14118.

Nutsugah, S.K., Leth, V., Atokple, I.D.K. and Tsigbey, F. K. 2003. Grain mould fungi from sorghum in Ghana. In: Sorghum and millets diseases Leslie, J.F. (Eds.), Iowa State Press, Ames, Iowa, USA. doi: 10.1002/9780470384923.ch38.

Ochieng, L.A., Mathenge, P.W. and Muasya, R. 2011. A survey of on-farm seed production practices of sorghum (Sorghum bicolor L. Moench) in Bomet district of 
Kenya. African Journal of Food, Agricultural Research 11(5):1-22.

Prom, I.K., Peruma, I.R., Erattaimuthu, S.R., Erpelding, J.E., Montes, N. Odvody, G.N., Greenwald, C., Jin, Z., Frederiksen, R. and Magil, C.W. 2011. Virulence and molecular genotyping studies of Sporisorium reilianum isolates in sorghum. Plant Diseases 95:523-529.

Rana, B.S. and Singh, B.U. 1995. Insect pest of sorghum and pearl millet panicles in Asia. In: Nwanze, K.F. and Youm, O., (Eds.), Panicle insects of sorghum and pearl millet: Proceedings of an International Consultative Workshop, 4-7 October. pp. 57-67. ICRISAT Sahelian Centre, Niamey, Niger. Patancheru 502 324, Andhra Pradesh, India: International Crop Research Institute for the Semi-Arid Tropics.

Ratnadass, A., Ajayi. O. Fliedel, G. and Ramaiah, K.V. 1995a. Host-plant resistance in sorghum to Eurystylus immaculations Odh. Proceedings of an International Consultative Workshop 4-7 October. pp. 191-199. ICRISAT. Patancheru, India.

Ratnadass, A. and Ajayi, O. 1995b. Panicle insect pests of sorghum in West Africa. In: Nwanze, K.F. and Youm, O. (Eds.), Panicle insects of sorghum and pearl millet: Proceedings of an International Consultative Workshop, 4-7 October. pp. 29-38. ICRISAT Sahelian Centre, Niamey, Niger. Patancheru 502 324, Andhra Pradesh, India: International Crop Research Institute for the Semi-Arid Tropics.

Ratnadass, A., Marley, P.S., Hamada, M.A., Ajayi, O., Cisse, B., Assamoi, F., Atokple, I.D.K., Beyo, J., Cisse, O., Dakouo, D., Diakite, M., Dossou-Yovo, S. Le Diambo, B., Vopeyande, M.B., Sissoko, I. and Tenkouano, A. 2003. Sorghum head bugs and grain moulds in west and central Africa: I. Host plant resistance and bug mould interactions on sorghum grains. Crop Protection. PII: S0261-2194 (03) 000668.
Sharma, H.C. 1985. Strategies for pest control in sorghum in India. Tropical Pest Management 31:167-185.

Sharma, H.C., Lopez, V.F. and Vidyasagar, P. 1994. Influence of panicle compactness and host plant resistance in sequential planting on population increase of paniclefeeding insects in sorghum. International Journal of Pest Management, 40, 216-221.

Sharma, H.C., Reddy, B.V.S., Dhillon, M.K., Venkateswaran, K., Singh, B.U., Pampapathy, G., Folkertsma, R.T., Hash, C.T. and Sharma, K.K. 2005. Host plant resistance to insects in sorghum: Present status and need for future research. SAT eJournal 1(1):1-8.

Sharma, H.C., Satyanarayana, M.V. Singh, S.D. and Stenhouse, J.W. 2000. Inheritance of resistance to head bugs and its interactions with grain moulds in Sorghum bicolor. Euphytica 112:167-173.

Sharma, R., Thakur, R.P., Senthilvel, S., Nayak, S., Reddy, B.V.S., Rao, V.P. and Varshney, R.K. 2010. Identification and characterization of toxigenic fusaria associated with sorghum grain mould complex in India. Mycopathologia 171: 223-230.

Showemimo, F.A., Alabi, S.O. and Olurunju, P.E. 2011. Importance and management of head bug (Eurystylus oldi Poppius) of sorghum in Nigeria. Academic Journal of Plant Sciences 4:26 - 29.

Singh, S. D. and Bandyopadhyay, R. 2000. Grain mould. In: Frederiksen, R.A. and Oddly, G.N. (Eds). Compendium of sorghum Diseases, The America Phytopathological Society, St. Paul, MN, USA. pp. 38-40.

Thakur, R.P., Reddy, B.V.S. and Mathur, K. (Eds.). 2007. Screening techniques for sorghum diseases. Information Bulletin No. 76. Patancheru 502 324, Andhra Pradesh, India: International Crops Research Institute for the Semi-Arid Tropics. p. 92. 
Thakur, R.P., Reddy, B.V.S., Rao, V.P., Garud, T.B., Agarkar, G.D. and Bhat, B. 2003. Sorghum grain mould: Resistant stability in advanced B-line. International Sorghum and Millet Newsletter 44:108-112.

Thomas, M.D. 1992. Sorghum diseases in western Africa. In: de Milliano, W.A.J., Frederiksen, R.A. and Bengston, G.D.
(Eds.). Sorghum and millets diseases, a Second World Review. ICRISAT, Patancheru, Andhra Pradesh, India. pp. 25-29.

Williams, R.J. and McDonald, D. 1983. Grain moulds in the tropics: problems and importance. Annual Review of Phytopathology 21:153-178. 